\title{
REFERENCES
}

Boulton, G. S. 1979. Processes of glacier erosion on different substrata. Journal of Glaciology, Vol. 23, No. 89. p. $15-38$.

Boulton, G. S., and Jones, A. S. 1979. Stability of temperate ice caps and ice sheets resting on beds of deformable sediment. Journal of Glaciology, Vol. 24, No. 90, p. 29-43.

Boulton, G. S., and others. 1974. Subglacial shearing and crushing, and the role of water pressures in tills from southeast Iceland, by G. S. Boulton, D. L. Dent, and E. M. Morris. Geografiska Annaler, Vol. 56A. Nos. 3-4. p. $135-45$.

Brace, W. F., and others. 1968. Permeability of granite under high pressure, by W. F. Brace, J. B. Walsh, and W. T. Frangos. Journal of Geophysical Research, Vol. 73, No. 6, p. 2225-36.

Einstein, A. 1906. Eine neue Bestimmung der Moleküldimensionen. Annalen der Physik, Ser. 4. Bd. 19. Ht. 2. p. $289-306$.

Engelhardt, H. F. 1978. Water in glaciers: observations and theory of the behaviour of water levels in boreholes. Zeitschrift für Gletscherkunde und Glazialgeologie, Bd. 14, Ht. 1, p. 35-60.

Engelhardt, H. F., and others. 1978. Basal sliding and conditions at the glacier bed as revealed by bore-hole photography, by H. F. Engelhardt, W. D. Harrison, and [W.| B. Kamb. Journal of Glaciology, Vol. 20, No. 84. p. 469-508.

Frisch, H. S., and Simha, R. [ $\left.{ }^{\mathrm{c}} 1956.\right]$ The viscosity of colloidal suspensions and macromolecular solutions. (In Eirich, F. R., ed. Rheology. Vol. 1. New York, Academic Press, p. 562-613.)

Hodge, S. M. 1979. Direct measurement of basal water pressures: progress and problems. Journal of Glaciology, Vol. 23, No. 89, p. 309-19.

Johnson, A. M. [' 1970.] Physical processes in geology. San Francisco, Freeman, Cooper and Co.

Jones, A. S. 1979. The flow of ice over a till bed. Journal of Glaciology, Vol. 22, No. 87, p. 393-95.

Roscoe, R. 1952. The viscosity of suspensions of rigid spheres. British Journal of Applied Physics, Vol. 3, No. 8, p. 267-69.

SIR,

\section{Short-term irregularities of discharge of glacial melt-water streams}

Sudden falls in the discharge of a glacial melt-water stream, sometimes to less than half the previous discharge, followed by an equally rapid rise, have been recorded from a number of glaciers, including Austre Okstindbreen, Norway (personal communication from W. H. Theakstone) and Gornergletscher, Switzerland, (personal communication from P. L. Comer). They appear on the discharge record as events lasting at most half an hour, and sudden fall and rise is sometimes followed by a small peak before the discharge returns to its natural level. Because these events have not been observed directly, they have most commonly been attributed to malfunctioning of the water-level recording equipment.

Ballantyne and McCann (1980) observed this pattern from an ice marginal stream on Ellesmere Island and, because of the frequency of the events, ascribed them to collapse of the ice margin, which caused temporary blocking of the stream.

The distinctive pattern of such events was seen on the discharge records of the outflow stream of the Pasterzengletscher, Austria, during the summer of 1980 (Fig. 1). The hydrograph shows that the events occurred in clusters, being concentrated in early August and at times of high discharge. One was observed as it occurred by Dr P. Ramspacher on 27 August. At about $16.00 \mathrm{~h}$. the discharge was seen to fall to a very low level and, as the water level subsequently started to rise, the stream became heavily laden with sediment and carried many small ice blocks. No collapse of the ice margin into the stream had occurred. Temporary damming of the stream, therefore, must have been caused by collapse of the subglacial tunnel up-stream of the portal. However, it is unlikely that the collapse occurred very far up-glacier, as the sharp features of the discharge hydrograph were not smoothed. It is probable that the thin ice close to the snout is most commonly subject to collapse, and high discharges appear to precipitate these events. 

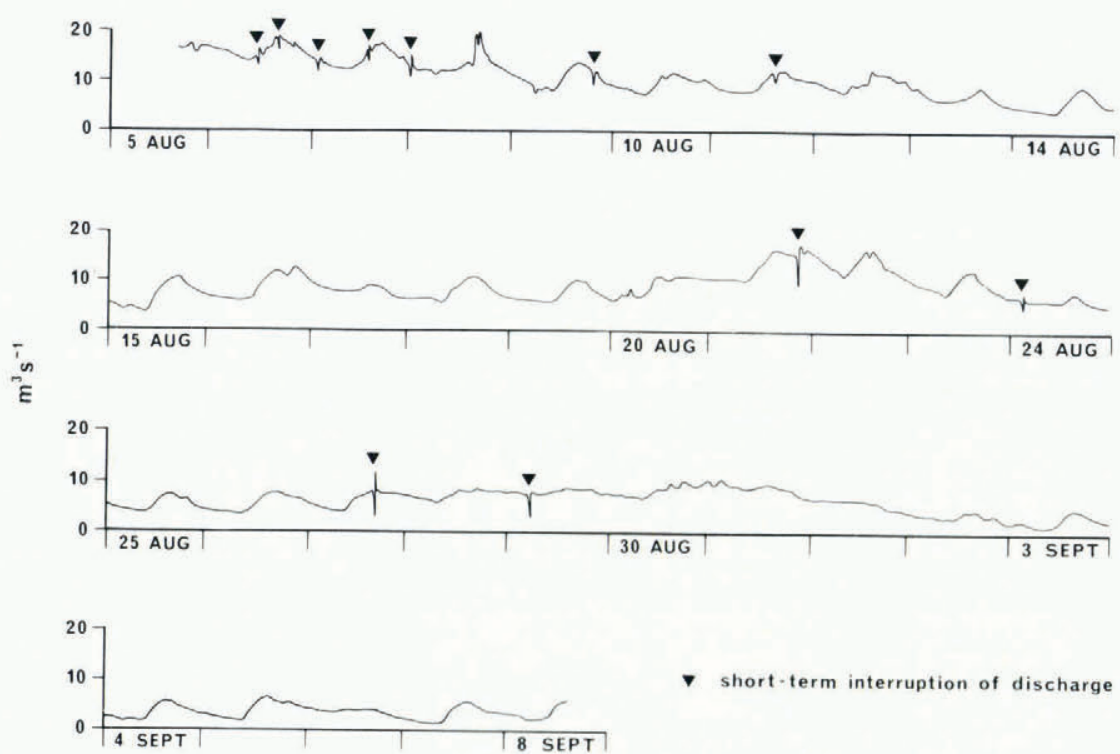

- short-term interruption of discharge

Fig. 1. Discharge hydrograph for Pasterzengletscher, Austria, summer 1980.

The direct evidence of this particular discharge irregularity at Pasterzengletscher casts doubt on explanations that similar records elsewhere were caused by faults of the recording equipment. Discharge records from other glaciers should be re-examined to see if evidence of such events is common.

Department of Geography,

University of Manchester,

M. BURKIMSHER

Manchester M13 9PL, England

7 July 1982

\section{REFERENCE}

Ballantyne, C. K., and McCann, S. B. 1980. Short-lived damming of a high-Arctic ice-marginal stream, Ellesmere Island, N. W. T., Canada. Journal of Glaciology, Vol. 25, No. 93, p. 487-91. 